\title{
Investigating Chinese EFL College Students' Writing Through the Web-Automatic Writing Evaluation Program
}

\author{
Zongwei Song ${ }^{1}$ \\ ${ }^{1}$ School of Foreign Languages, Sichuan University of Arts and Science, Dazhou, China \\ Correspondence: Zongwei Song, School of Foreign Languages, Sichuan University of Arts and Science, Dazhou, \\ China. E-mail: songzongwei2008@126.com
}

Received: July 13, 2019 Accepted: August 10, 2019 Online Published: August 26, 2019

doi:10.5539/ells.v9n3p20 URL: https://doi.org/10.5539/ells.v9n3p20

\begin{abstract}
WWE-pigai is a kind of upgraded automated writing evaluation (AWE) system and there are 444,877,400 essays submitted and corrected on this platform. Some previous research on AWE system indicates that students do not tend to utilize AWE feedback to revise essays and improve writing abilities. The major objective of this study is to investigate Chinese EFL college students' writing through the comparison of WWE-pigai and traditional writing method. The study lasts two terms and 120 Chinese colleges students participate in the research. The findings reveal that WWE-pigai can motivate EFL students to revise and resubmit their essays more than ten times, improve the scores, increase students' grammar accuracy and vocabulary richness. The surface-level spelling errors (including punctuation mark misuse) are the most common for freshmen. WWE-pigai is not very effective to correct certain grammatical errors besides spelling and conjugation errors. For certain grammatical errors that the students cannot correct by themselves, the assistance of EFL teachers is necessary. We argue that the results reached through this study can offer useful implications for the usage of EFL writing strategies.
\end{abstract}

Keywords: EFL writing, WWE-pigai, evaluation program

\section{Introduction}

\subsection{Web-Automatic Writing Evaluation Program}

In the past decade, the emergence of various web-automatic writing evaluation (WWE) programs supported by corpora, cloud computing and sophisticated language processing technologies has changed EFL writing. WWE programs are the upgraded versions of the automated writing evaluation (AWE) system. There is an increasing tend to use WWE programs to evaluate the writing due to many strengths compared with traditional writing method. More and more college students submit their compositions through WWE programs, which can score and comment the writing within a second, and give students feedback. Some studies reveal the nature of AWE which includes elicitors, appraisals, and effects on self-concept (Shiota, Keltner, \& Mossman, 2007). There have been relevant studies focusing on reliability of AWE scoring (Attali, Lewis, \& Steier, 2012), pedagogical practices of AWE (Chen \& Cheng, 2008), and students' perceptions and emotional involvement toward AWE (Wang \& Goodman, 2012). Compared with the traditional manual reviewers, WWE programs or AWE systems possess a great number of advantages which include improvement of EFL writing interest, immediacy of online comments (Dikli, 2006), diagnostic feedback and holistic scores (Shermis \& Burstein, 2003), multiple drafting chances (Warschauer \& Ware, 2006), positive impact on EFL writing (Zhang, 2016).

\subsection{Literature Review}

Some previous studies indicate that EFL students do not make good use of AWE feedback on their writings and redrafting frequency is low. Attali (2004) reports in a study that there are 71 percent of student essays without any redrafting, and only a small proportion of students revise essays according to the AWE feedback. Ebyary and Windeatt (2010) point out that only about 45 percent of 549 Egyptian EFL trainees never wrote a second draft after using the commercially AWE program 'Criterion ${ }^{\circledR}$ '. It is claimed that students do not make other changes in the writing such as collocations or sentence structures in multiple revisions, though they are able to correct grammar errors and spelling errors diagnosed by AWE (Zhang, 2016). Hence, some researchers claim that AWE feedback can not improve students' revising ability (Stevenson \& Phakiti, 2014). Low redrafting times, and insufficient collocation and structure revisions may be resulted from the shortcomings of some AWE systems 
such as lack of convenience, lack of tips and suggestions for revisions, and absence of free access. Fortunately, the WWE program called Pigai (WWE-pigai, Note 1) can overcome the aforementioned shortcomings of AWE systems and have positive impacts on EFL writing, which is elaborated in this research.

This research investigates Chinese EFL colleges' students writing through the web-automatic writing evaluation program which lasts for 10 months on the basis of 120 Chinese college students. It is indicated that WWE-pigai can be massively applied in the EFL writing with a view to encouraging EFL students to increase the times of revisions and re-submissions, improve EFL scores, automatically analyze and report the various errors in EFL writings.

\section{Methodology}

\subsection{Research Questions}

In this research, the following three questions related to EFL writing on the basis of WWE-pigai are studied: (a) Can WWE-pigai encourage EFL students to increase the times of revisions and re-submissions? (b) Can WWE-pigai improve EFL writing scores? (c) What are common errors in the EFL writing and can they be automatically corrected by EFL students?

\subsection{Research Subjects}

The subjects of this research are 120 Chinese college students and the author teaches them college English course. They are all freshmen. In the college entrance examination, their English scores are 80 to 110 out of total 150 points, which means that they initially have the same English level in this research. According to the school's requirement, all of them are required to participate in the College English Test Band 4 (CET-4, Note 2) which is semi-annually held in China, and the first part of CET-4 is writing, accounting for 15 percent of total score. Hence, the students practice English writing in the College English course. The 120 college students are grouped into two classes: class one and class two. Class one has 60 students and is based on WWE-pigai writing in the course; Class two has 60 students and is based on traditional writing method in English course, which means that they are required to hand in the compositions in paper, and the author comments, scores them and gives feedback. The research lasts two terms: namely, the first term and the second term in the grade one (from September 2017 to July 2018).

\subsection{Research Instruments}

This research is based on WWE-pigai for EFL writing and for the statistical analysis of the elicited data. WWE-pigai is a massive-open-online EFL writing and evaluated system, which is designed mainly for EFL learners whose first language is Chinese, and there are more than 444,877,400 essays submitted and corrected in WWE-pigai and the number is increasing by the minute (Note 3). Because of the convenience, friendly-interface and good effect, WWE-pigai attracts almost all the students from Chinese colleges and some high schools (Note 4). Hence, based on WWE-pigai, this research can, to a great degree, reflect features and efficiency of the EFL writing based on WWE program.

\subsection{Procedures}

The following seven procedures primarily include dividing 120 college students into two groups of class one and class two, accumulating the feedback respectively, comparing, analyzing the relevant scores from two classes and finding the error types EFL students have made.

(a) Divide groups and assign writing assignments. Within two terms, 60 students in class one have been required to finish six composition assignments about 120 words every other month on WWE-pigai. The topics of the six compositions in sequence of finished time and are numbered: (No. 1) the most impressing course in my college life, (No. 2) Spring Festival, (No. 3) selfishness in the dormitory life, (No. 4) judging people by appearance, (No. 5) how to tell Chinese stories in English, and (No. 6) about online loan.

(b) Traditional writing and feedback for class two. Students in class two have been required to finish the six composition assignments with the same requirements (and in the same time) as class one but they should write them in paper (not on WWE-pigai), hand them in, and then the author comments them and gives feedback.

(c) Input the essays handed in by the 60 students in class two into WWE-pigai and score them through WWE-pigai with the same criterion. The author manually input the 360 essays on the aforementioned topics into WWE-pigai, which are used to make comparison between class one and class two on the efficiency of WWE-pigai. The 360 essays are classified into six groups according to aforementioned six topics and are automatically scored by WWE-pigai.

(d) Count up the average times of revisions and re-submission for each composition assignments in class one, 
and observe the diachronic change of the average times.

(e) Count up the holistic scores and observe diachronic change of the scores of the six-composition assignment in class one.

(f) Compare the holistic average score of six composition assignments in class one with that in class two.

(g) Analyze error types of 60 students in class one, which is used to give evidence to the claim that some errors are easily corrected by EFL students during WWE-pigai based writing, and certain grammatical errors are not easily corrected by EFL students themselves. The error types are automatically reported in WWE-pigai: in the sub-menu 'error statistics' of the 'term report' menu, at the bottom of 'browsing homework'.

\section{Findings}

\subsection{The Increase of Average Revision Times}

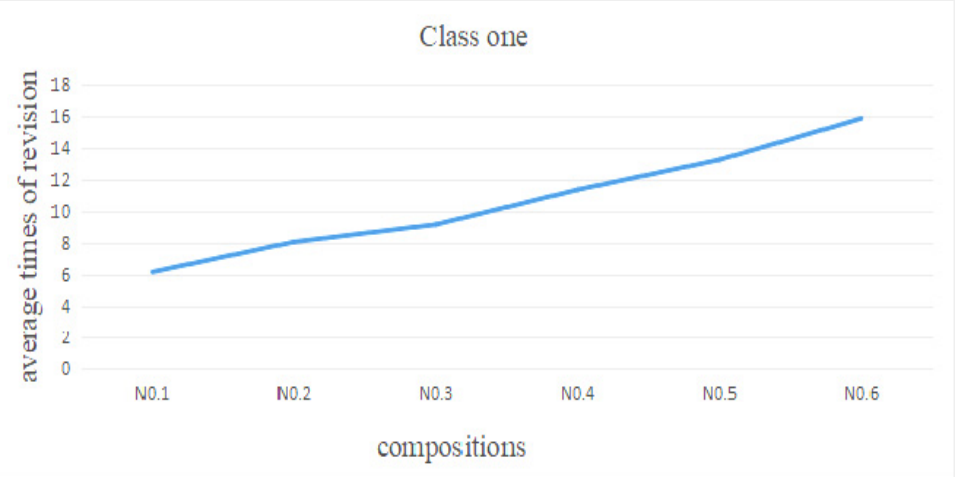

Figure 1. The average times of submission for six composition assignments in class one

The average revision frequency of the six composition assignments in class one is gradually increasing. As is illustrated in Figure 1, the first composition (No. 1) is averagely revised six times on WWE-pigai, by the students in class one; the second composition (No. 2) is averagely revised eight times after the students are told the importance of self-revision in WWE-pigai. The increase of the revision frequency may also be motivated by the rise of the holistic scores after each revision and re-submission. The students in class one are gradually developed the habit to revise their essays until they get satisfying scores. At the end of the second term, when they finished their No. 6 composition, the average revision frequency is 16 times. It can be seen that the increase of revision frequency of EFL writing based on WWE-pigai is contrary to some previous findings which suggest students seldom revise and resubmit the essays during the writing on AWE systems (Attali, 2004; El Ebyary \& Windeatt, 2010).

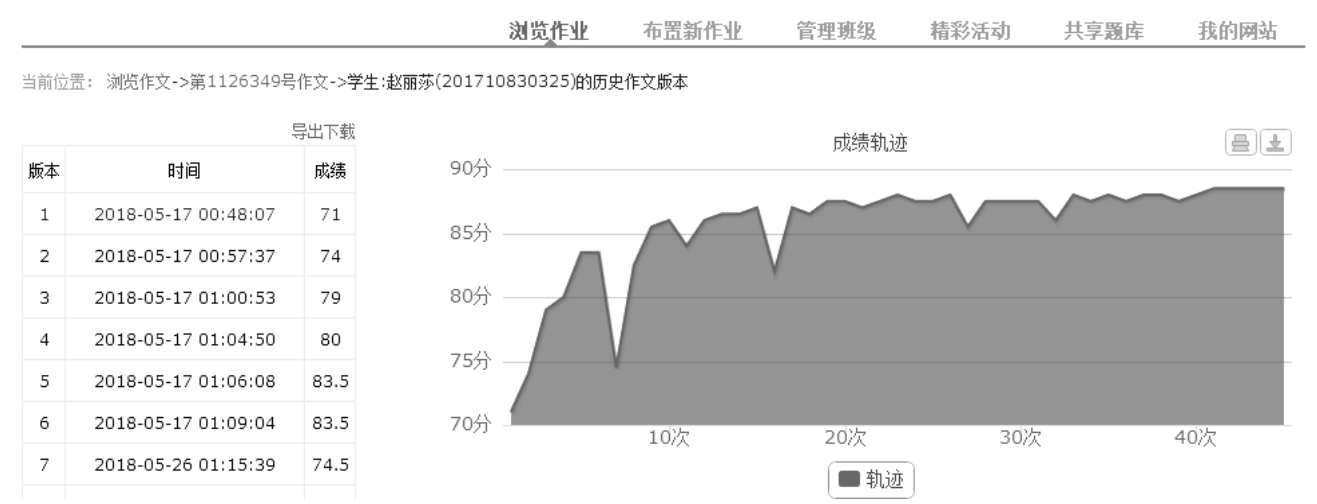

Figure 2. The track of revisions and scores of a student in class one (this is an example of Figure 2)

As shown in Figure 2, there is a case that the author's student, called Lisha Zhao, has revised and resubmitted her manuscript in No. 5 more than 45 times, and the scores from the initial version 71 points to the finial version 
88.5 points. It is reported that there are some students who revise and resubmit their essays in WWE-pigai more than two hundred times during the EFL writing practices. This track of revisions indicates that the EFL students are greatly motivated by WWE-pigai to revise essays.

\subsection{The Better Scores from WWE-Pigai in Comparison with Traditional Ones}

Though the six composition assignments are with the same requirement, finished in the same period by class one and class two, and scored by the same system (Note 5), there exists obvious difference in the average holistic scores.

Table 1. Six composition assignment average holistic scores (Note 6) of class one and class two

\begin{tabular}{lll}
\hline Composition No. & class one & class two \\
\hline No. 1 & 78.74 & 72.1 \\
No. 2 & 79.82 & 73.21 \\
No. 3 & 81.2 & 75.61 \\
No. 4 & 82.51 & 78.31 \\
No. 5 & 83.4 & 78.3 \\
No. 6 & 85.44 & 79.1 \\
Average & 81.85 & 76.11 \\
\hline
\end{tabular}

As indicated in Table 1, the scores (from No. 1 to No. 6) of class one are gradually rising, which conforms to the rising trend of average revision frequency of each composition assignment (see Figure 1). The more average revision in class one, the higher scores are. Though from diachronic perspective the average scores of class two are also gradually rising, this is the result of improvement of writing ability after six EFL writing practices. The author may say that revision frequency is one of important factors impacting on the EFL writing scores and abilities.

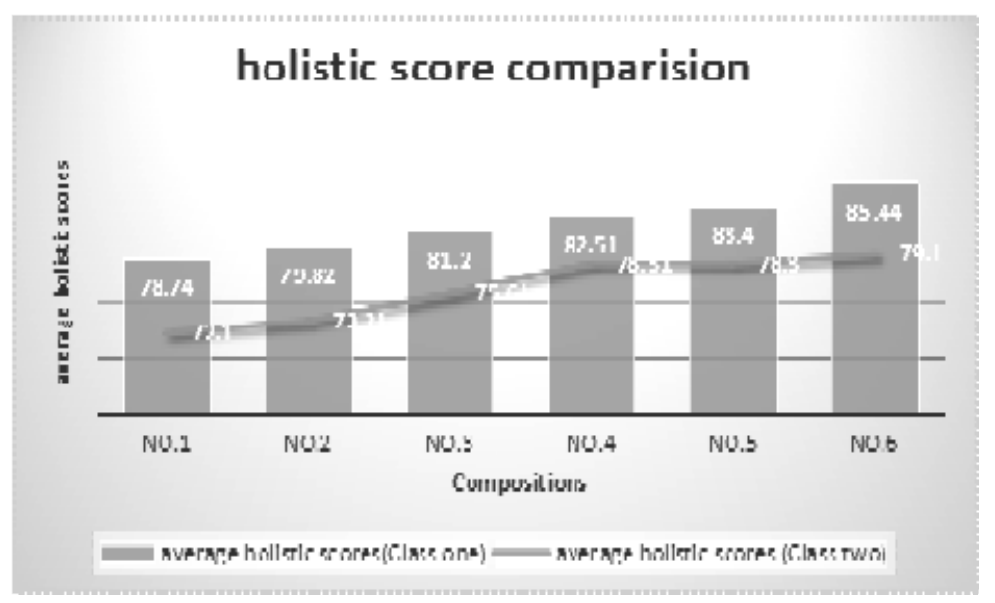

Figure 3. Average holistic score comparison between class one and class two

As illustrated in Figure 3, the average scores of each composition assignment in class one are higher than ones in class two, which suggests (a) the scores of EFL writing based on WWE-pigai are better than ones based on traditional non-AWE program, and (b) the multiple revisions in EFL writing can raise the scores. 


\subsection{The Increase of Grammatical Accuracy}

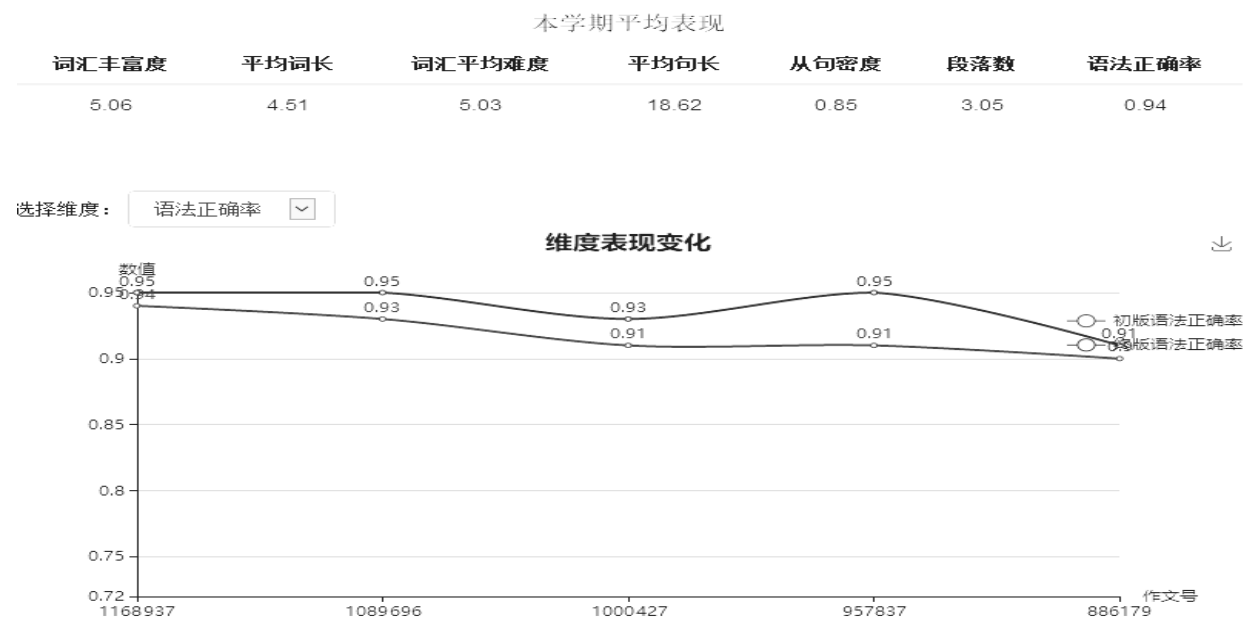

Figure 4. Grammatical accuracy change of the initial version and the finial version

It is indicated that the grammatical accuracy is increasing after revisions and re-submissions based on WWE-pigai. Figure 4 shows that the grammatical accuracy of finial version of each composition is improved, comparing to their corresponding initial submissions. From Figure 4, the holistic grammatical accuracy (Note 7) of No. 2 (marked 957837 in WWE-pigai), is 0.91 in initial submission and reaches 0.95 in the finial version after many times' revisions based on WWE-pigai. Various tips and revision suggestions given by WWE-pigai are helpful for the EFL writing, especially for improving the grammatical accuracy, and further develop the awareness of correcting grammatical errors.

\subsection{The Improvement of Vocabulary Richness}

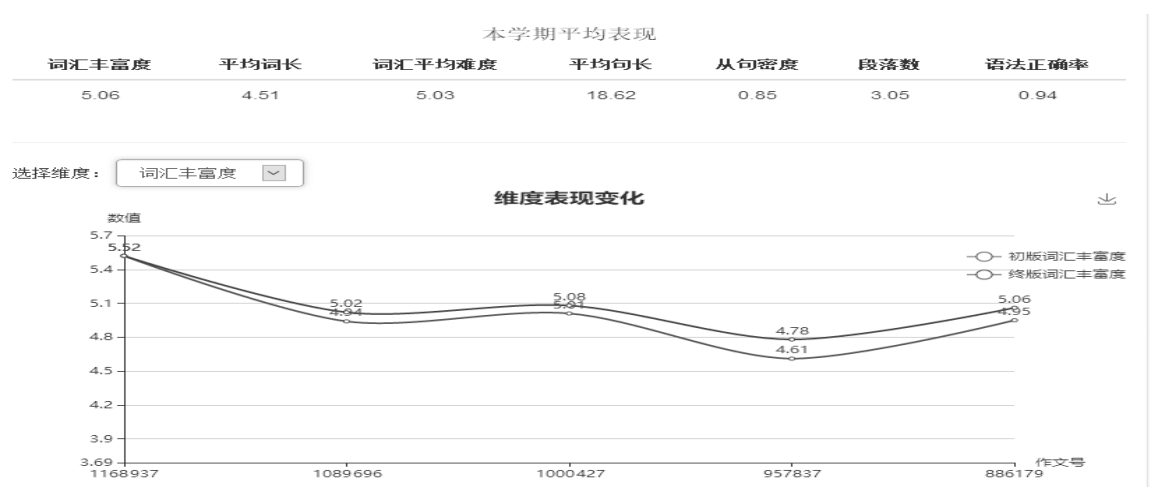

Figure 5. The change of vocabulary richness

It is statistically reported that the vocabulary richness in the EFL writing based on WWE-pigai is gradually improving, as is shown in Figure 5. The vocabulary richness of the final submission of each composition is larger than that of the initial submission. Though the vocabulary richness in EFL writing is affected by various factors, such as learning time, essay topics, teachers' guide, and so on, the tips and suggestions given by WWE-pigai and the multiple revisions and re-submissions are one of key factors resulting in the improvement of vocabulary richness. The author may say that EFL writing based on WWE-pigai or other AWE systems can improve the vocabulary richness.

\subsection{The Types of Errors in EFL Writing}

WWE-pigai not only provides tips and suggestions for students to revise their essays, but also provides various statistical analyses to reveal the common errors in EFL writings, which are very useful for the EFL teachers to 
guide students' writings.

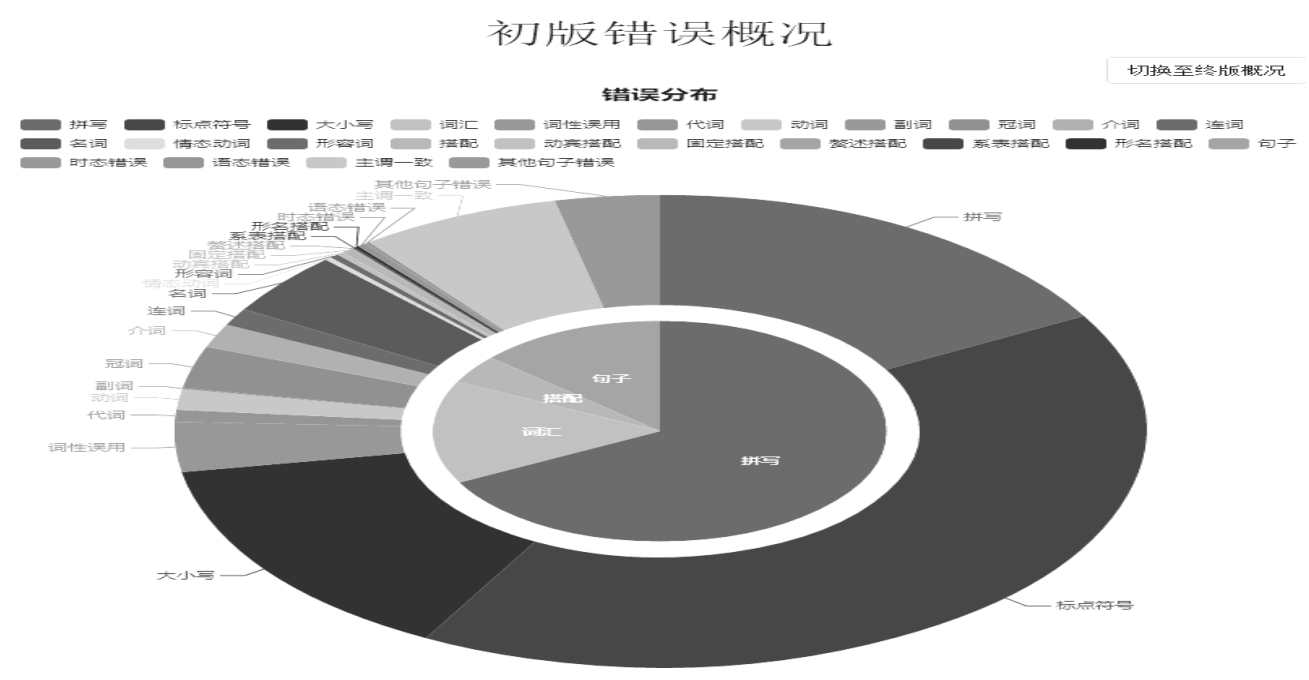

Figure 6. Error distribution report

As shown in Figure 6, there are error statistics and analysis for the six writing assignments in class one. In the initial versions, there are four types of errors including spelling, sentence, vocabulary, and collocation. The spelling errors (including punctuation mark misuse) account for more than 65 percent in the initial version of the six writing assignments in class one. Vocabulary errors account for approximately 15 percent. Sentence errors account for approximately 16 percent and collocation errors account for approximately 4 percent. Based on these statistics and analyses, it can be said that the most common errors in EFL writings of Chinese college students are the spelling errors. As a matter of fact, WWE-pigai provides detailed three-level error reports to the submitted essays in each term (see details in the Appendix A). Hence, EFL teachers should pay more attention to the spelling errors when they guide their students' writing, especially for freshmen in China. To different EFL writing students, the EFL writing teachers can also adjust their guidance according to the error reports in WWE-pigai.

\subsection{Corrected Rate of Different Error Types}

It is reported that there are 1,449 grammatical errors in the six writing assignments for class one and 354 out of 1,449 grammatical errors are corrected in the revised and resubmitted versions. It means that the corrected rate of grammatical errors is 24 percent. This partially conforms to the findings that AWE can reduce some grammar errors (Liao, 2016) and for most of grammatical errors can not be corrected by students on WWE-pigai.

本学期学生在初版作文中共发生语法错误 1449 处, 通过自主修改, 修正错误 354 处, 修正率达到 $24.4 \%$ 。

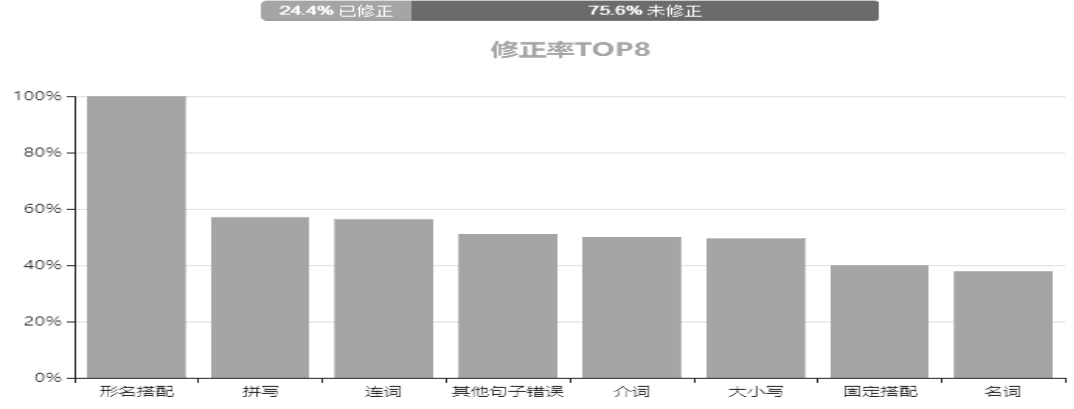

Figure 7. Top 8 corrected errors 
Corrected rates of the top 8 are illustrated in Figure 7, which is automatically calculated and reported by WWE-pigai in the sub-menu 'error statistics' of the 'term report' menu. The corrected rate of 'adjective plus noun' is 100 percent, which means that this kind of errors are completely corrected by EFL students in class one during the WWE-pigai based writings. The corrected rates of 'spellings' and 'conjunctions' are top 2 and top 3, which suggests that more than 57 percent of them are corrected in the finial submissions. It can be seen that some types of errors, in the EFL writings based on WWE-pigai, are easily corrected by students with the help of the tips or suggestions given by the program, and other types of errors are not easily corrected such as certain grammatical errors. For the spelling and conjugation errors, WWE-pigai is efficient. However, to certain grammatical errors it is not efficient. The corrected rate of the grammatical errors in class one is no more than 24 percent, which means that WWE-pigai is not efficient for EFL students to correct certain grammatical errors in the writing practices. The grammatical errors in EFL writings can not completely rely on WWE-pigai or other AWE programs to practice and correct, and EFL writing teachers should help students to recognize and correct certain grammatical errors with other methods.

\section{Discussion}

In this study, the students in class one are found to repeatedly revise and resubmit their compositions in WWE-pigai in order to obtain satisfactory holistic scores. The times of revision and re-submission are motivated by the instant holistic scores given by WWE-pigai after each submission. When students find the holistic scores gradually rising, they tend to check and revise compositions till scores do not rise. Another factor forcing the students to repeatedly revise their composition is the various tips and suggestions for revising compositions after each re-submission. There are various tips and suggestions such as spelling errors, grammatical errors, sentence errors, collocation errors, tense errors, and so on, which are automatically provided by WWE-pigai after each submission. Students can easily correct some of the suggested errors and have better scores so that they can reflect their willingness to increase the times of revision and re-submission. The findings that the students in class one tend to increase times of revision and re-submission in WWE-pigai (see Figure 1) are contrary to the findings of previous related research (Attali, 2004; Ebyary \& Windeatt, 2010), which advocates that the EFL students are not likely to revise and resubmit essays on AWE systems. The reason may be that there is a myriad of advantages of WWE-pigai which include instant multiple feed-backs, being free accessible via online and mobile phone, interface-friendly, and so on.

WWE-pigai can improve EFL writing scores. It is found that students in class one have better holistic scores for each composition assignments based on WWE-pigai than students in class two in this research. Though there are the same topics, the same requirement, the same time and the same scoring criteria, the scores in class one are better than class two (see Table 1). Hence, WWE-pigai is beneficial for improving EFL writing scores. That is why there are so many college students and high school students practising English writing on WWE-pigai in China. One evidence for this claim is that there are more than 444,877,400 essays submitted on this platform, and the number is increasing by the minute.

There are various errors made in EFL writings and the errors are automatically analysed and reported. According to the error report to the six assignments for class one, the corrected rate of the grammatical errors is very low: 24 percent. That means that there are 86 percent of grammatical errors which have not been corrected by students in class one. To these grammatical errors on WWE-pigai, EFL teachers had better resolve them by other methods in writing class, not just relying on self-correction on WWW-pigai. However, to the 'adjective plus noun' errors, spelling errors, and conjunction errors, the correction rate is high. To those errors, EFL students can correct them by themselves on this platform, which can save a great amount of time for EFL teachers. Indeed, WWE-pigai can efficiently help resolve some surface-level errors, such as spelling errors, conjunction errors, while to certain grammatical errors the help of EFL teachers is necessary in class. This is one of important implications for EFL writing based on WWE-piai or other AWE programs.

\section{Conclusion}

This research investigates the EFL writing based on WWE-pigai. The major objective of this study is to investigate Chinese EFL College Students' writing which is based on the comparison of WWE-pigai and traditional writing method. The study lasts two terms and 120 Chinese colleges students who are divided into two groups participate in the research.

The findings reveal that: (a) WWE-pigai can motivate EFL students to revise and resubmit their essays more than ten times in order to obtain a better holistic score on this platform (b) WWE-pigai can improve the EFL writing scores in class one, compared with traditional writing method in class two (c) WWE-pigai can increase students' grammatical accuracy and improve vocabulary richness (d) the surface-level spelling errors (including 
punctuation mark misuse) are the most common for freshmen. WWE-pigai is not very effective to correct certain grammatical errors in the writing practices besides spelling and conjugation errors. For certain grammatical errors that the students from WWE-pigai cannot correct by themselves, the assistance of EFL teachers is indispensable for better teaching effect. It can be said that WWE-pigai encourages EFL students to revise their essays, improve writing scores, enrich grammar accuracy and vocabulary, which contribute to the improvement of writing ability for EFL college students.

Furthermore, the results reached through this study offer useful implications for the usage of EFL writing strategies. WWE-pigai is relatively effective to improve students' writing from many aspects. Therefore, the teachers make the most of WWE-pigai with a view to raising their interest and strengthening their confidence. In this case, students writing ability can be improved in the long run. Moreover, in classroom teaching the teachers also pay more attention to correcting spelling errors for freshmen. However, due to students' personal mental difference and change, the classification for class one and class two is not absolutely precise. This probably exerts some influence on inaccuracy of the statistics from the study results to some extent.

\section{Acknowledgments}

Funding: This work was supported by A Project Supported by Center for Rural Childhood Education Research [Grant No.: NYJ20150607] and by A Project Supported by Sichuan University of Arts and Science [Grant No.: 2017JY18]

\section{References}

Attali, Y. (2004, April). Exploring the feedback ad revision features of Criterion. Paper presented at the National Council on Measurement in Education (NCME), San Diego, CA.

Attali, Y., Lewis, W., \& Steier, M. (2012). Scoring with the computer: alternative procedures for improving the reliability of holistic essay scoring. Language Testing, 30(1), 125-141. https://doi.org/10.1177/0265532212452396

Chen, C-F., \& Cheng, W-Y. (2008). Beyond the design of automated writing evaluation: pedagogical practices and perceived learning effectiveness in EFL writing classes. Language Learning \& Technology, 12(2), 94-112.

Dikli, S. (2006). An overview of automated scoring of essays. Journal of Technology, Learning and Assessment, $5(1), 1-35$.

EI Ebyary, K., \& Windeatt, S. (2010). The impact of computer-based feedback on students' written work. International Journal of English Studies, 10(2), 121-142. https://doi.org/10.6018/ijes/2010/2/119231

Liao, H. C. (2016). Using automated writing evaluation to reduce grammar errors in writing. Elt Journal, 70(3), 308-319. https://doi.org/10.1093/elt/ccv058

Shermis, M. D., \& Burstein, J. C. (2003). Automated Essay Scoring: A Cross-disciplinary Perspective. Hillsdale, NJ: Lawrence Erlbaum Associates. https://doi.org/10.4324/9781410606860

Shiota, M. N., Keltner, D., \& Mossman, A. (2007). The nature of awe: Elicitors, appraisals, and effects on self-concept. Cognition \& Emotion, 21(5), 944-963. https://doi.org/10.1080/02699930600923668

Stevenson, M., \& Phakiti, A. (2014). The effects of computer-generated feedback on the quality of writing. Assessing Writing, 19(1), 51-65. https://doi.org/10.1016/j.asw.2013.11.007

Wang, M-J., \& Goodman, D. (2012). Automated writing evaluation: students' perceptions and emotional involvement. English Teaching \& Learning, 36(3), 1-37.

Warschauer, M., \& Ware, P. (2006). Automated writing evaluation: defining the classroom research agenda. Language Teaching Research, 10(2), 157-180. https://doi.org/10.1191/13621688061r190oa

Zhang, Z. (2016). Student engagement with computer-generated feedback: a case study. Elt Journal, 71(3), 317-328. https://doi.org/10.1093/elt/ccw089

\section{Notes}

Note 1. See http://www.pigai.org

Note 2. CET-4 and CET-6 are national English test for Non-English major university students in China, and there are more than 96,200,000 candidates for this test in June, 2017. 
Note 3. See the instant information website: https://www.pigai.org/?a=pad3

Note 4. See the typical user information: http://www.pigai.org/index.php?c=us\&a=baogao

Note 5. In this research, the 360 essays of class two are manually inputted into WWW-pigai to score in the same criterion in order to make the comparison.

Note 6. Holistic score means an overall score generated by WWE-pigai for each composition based upon the holistic rubrics of the system; the full holistic score is 100 .

Note 7. The holistic grammatical accuracy is automatically calculated and reported by WWE-pigai.

\section{Appendix A}

Three-level errors' report to six assignments of class one (screenshot)

\begin{tabular}{|c|c|c|c|c|c|c|c|}
\hline 一级 & 二级 & 三级 & 统计 & & 比例 & 统计 & 比例 \\
\hline \multirow{3}{*}{ 拼写 } & 拼写 & \multicolumn{3}{|c|}{156} & $10.96 \%$ & \multirow{3}{*}{919} & \multirow{3}{*}{$64.54 \%$} \\
\hline & 标点符号 & \multicolumn{3}{|c|}{611} & $42.91 \%$ & & \\
\hline & 大小写 & \multicolumn{3}{|c|}{152} & $10.67 \%$ & & \\
\hline \multirow{22}{*}{ 词汇 } & \multirow{7}{*}{ 词性误用 } & 动词误用为名词 & 15 & \multirow{7}{*}{42} & \multirow{7}{*}{$2.95 \%$} & \multirow{22}{*}{218} & \multirow{22}{*}{$15.31 \%$} \\
\hline & & 副词误用为形容词 & 3 & & & & \\
\hline & & 名词误用为动词 & 3 & & & & \\
\hline & & 名词误用为形容词 & 8 & & & & \\
\hline & & 形容词误用为副词 & 4 & & & & \\
\hline & & 形容词误用为名词 & 6 & & & & \\
\hline & & 其它词性误用 & 1 & & & & \\
\hline & 代词 & \multicolumn{3}{|l|}{11} & $0.77 \%$ & & \\
\hline & \multirow{3}{*}{ 动词 } & 动词属性 & 3 & \multirow{3}{*}{19} & \multirow{3}{*}{$1.33 \%$} & & \\
\hline & & 动词形态 & 7 & & & & \\
\hline & & 非谓语动词 & 5 & & & & \\
\hline & 副词 & \multicolumn{3}{|l|}{1} & $0.07 \%$ & & \\
\hline & \multirow{3}{*}{ 冠词 } & 冠词多余 & 5 & \multirow{3}{*}{47} & \multirow{3}{*}{$3.30 \%$} & & \\
\hline & & 冠词缺失 & 19 & & & & \\
\hline & & 冠词误用 & 8 & & & & \\
\hline & \multirow{3}{*}{ 介词 } & 介词多余 & 2 & \multirow{3}{*}{20} & \multirow{3}{*}{$1.40 \%$} & & \\
\hline & & 介词缺失 & 3 & & & & \\
\hline & & 介词误用 & 15 & & & & \\
\hline & 连词 & \multicolumn{3}{|l|}{17} & $1.19 \%$ & & \\
\hline & \multirow{2}{*}{ 名词 } & 名词单复数 & 35 & \multirow{2}{*}{52} & \multirow{2}{*}{$3.65 \%$} & & \\
\hline & & 名词可数性 & 3 & & & & \\
\hline & 情态动词 & 3 & & & $0.21 \%$ & & \\
\hline
\end{tabular}

\section{Copyrights}

Copyright for this article is retained by the author, with first publication rights granted to the journal.

This is an open-access article distributed under the terms and conditions of the Creative Commons Attribution license (http://creativecommons.org/licenses/by/4.0/). 